\title{
Rapping against Old and New Nazis: Bejarano and Microphone Mafia's Multidirectional Musical Memory Work
}

\author{
MONIKA E. SCHOOP
}

\begin{abstract}
Since 2008, the cross-generational and transcultural group Bejarano and Microphone Mafia, comprising of Auschwitz concentration camp survivor Esther Bejarano, her son Joram, and Kutlu Yurtseven and Rossi Pennino of the hip-hop duo Microphone Mafia, has made use of music to memorialize the Nazi period and the Holocaust in particular. In this article I examine the sounding memories of Bejarano and Microphone Mafia, drawing on participant observation in various performance contexts, semi-structured interviews with the group members, as well as an analysis of selected songs. Building on Michael Rothberg's theoretical framework of "multidirectional memory," I inquire into the songs and performances of the group as multidirectional musical memory work. Uncovering the multifaceted memory dynamics unfolding in their music and performances, I analyze how sounding memories of the Nazi period, and more recent memories of racist violence and far right terrorismincluding the torching of refugee centers in the 1990s and the killings perpetrated by the neo-Nazi network NSU in the early 2000s, as well as memories of migrants' experiences-especially those of the so-called Gastarbeiter generation-emerge in dialogue. My interrogation shows that songs and performances do not only serve as media of memory but give rise to new forms of solidarity and are envisaged as agents of change and social justice, which gain importance in the face of persisting racism and mounting calls to "move forward" from the Nazi past.
\end{abstract}

\section{Introduction}

It is January 27, 2015, the International Holocaust Remembrance Day and the seventieth anniversary of the liberation of Auschwitz concentration camp. Esther Bejarano steps on the stage of a Cologne theater in a former factory building. The diminutive woman of 90 years of age appears fragile as she takes a seat at a small desk in the center of the stage. The audience falls silent. Her voice is firm as she starts to read about her deportation to Auschwitz and her time as a member of the camp's orchestra; Esther bears witness to the inconceivable atrocities of the Nazi regime. Recounting her memories of the end of WWII and the liberation, Esther ends her testimony and invites the audience to what she terms "my revenge on the Nazis." Together with rapper Kutlu Yurtseven and her son Joram Bejarano, who plays the bass, she embarks on a musical journey, weaving together multiple histories of antifascist resistance. The three perform songs from the camps and ghettos_-partisan and Jewish songs, as well as original compositions_always combining multiple languages, including German, Turkish, French, Italian, and Yiddish. Today's repertoire ranges from a defiant intonation of the Jewish resistance song "Mir lebn eybig" to "Avanti Popolo" and "Bella Ciao." In their reworking of historical antifascist songs, and especially through the infusion of rap, they draw parallels between the Nazi atrocities and right-wing terrorism and racist attacks of the 1990s and the new century. The cross-generational and transcultural group of Esther, the Jewish concentration camp survivor, Joram, 
who was born in Israel, and Kutlu, the son of Turkish migrant workers, makes their voices heard against "old and new Nazis" and for a peaceful future.

In this article, I examine the contemporary relevance and use of the memorialization of the Nazi period and the Holocaust focusing on the sounding memories of Bejarano and Microphone Mafia. The group was formed in 2008 as a collaboration of Esther Bejarano-survivor of the Auschwitz and Ravensbrück concentration camps-her children Joram and Edna, and Kutlu Yurtseven, Rosario "Rossi" Pennino, and Önder Bardakci, ${ }^{1}$ founding members of the hip-hop group Microphone Mafia, one of the first German hip-hop acts. ${ }^{2}$ Leading up to the group's formation Kutlu had approached the Bejaranos about a collaboration after he was asked to join a campaign of the German Trade Union Confederation (DGB), which had set out to make memory work more accessible in order to counter the far right's distribution of propagandistic pamphlets and CDs outside schools. Since they began to collaborate, the group, today comprising Esther and Joram Bejarano, Kutlu Yurtseven, and Rossi Pennino, ${ }^{3}$ has so far released two albums, an EP, and two films, and has played over 600 concerts.

I inquire into the songs and performances of Bejarano and Microphone Mafia as multidirectional musical memory work. Considering musical practices as memory work is based on the assertion that "memory is best seen as a practice of remembrance and not a "thing,", ${ }^{\text {a }}$ view rooted in the performative turn in memory studies. This perspective allows me to analyze processes of memory making, exploring memory as it unfolds in the music and performance of the group. In order to do so, I draw on Michael Rothberg's concept of multidirectional memory laid out in his book Multidirectional Memory: Remembering the Holocaust in the Age of Decolonization. ${ }^{5}$ Rothberg criticizes the assumption brought forward by literary critic Walter Ben Michaels, among others, that collective memory is competitive and takes part in a "zero-sum struggle over scarce resources." Assuming that memories "crowd each other out in the public sphere," ${ }^{7}$ Holocaust remembrance would accordingly marginalize other memories of histories of extreme violence. ${ }^{8}$ Multidirectionality instead takes into account memory's interconnectedness and productivity, and acknowledges that it is "subject to ongoing negotiation, cross-referencing, and borrowing." Collective memories accordingly overlap, connect, and emerge dialogically. I argue that despite the fact that Holocaust remembrance is a key concern of the group, the musical memory work of Bejarano and Microphone Mafia goes far beyond addressing the Nazi period. Framing the group's memory work as multidirectional allows me to uncover the multifaceted memory dynamics unfolding in the group's music and

\footnotetext{
${ }^{1}$ Edna Bejarano and Önder Bardakci left the group after the first album Per La Vita (2009).

${ }^{2}$ Microphone Mafia was founded in 1989. On the history of the band, see Kutlu Yurtseven and Rossi Pennino, Eine ehrenwerte Familie: Die Microphone Mafia - Mehr als nur Musik(Cologne: PapyRossa, 2019); Monika E. Schoop, "Standing up against Discrimination and Exclusion: An Interview with Kutlu Yurtseven," in Made in Germany: Studies in Popular Music, ed. Oliver Seibt, Martin Ringsmut, and David-Emil Wickström, 207-15 (New York: Routledge, 2020), https://doi.org/10.4324/9781351200790-26.

${ }^{3}$ Rossi only takes part in a limited number of the group's live performances due to his occupational responsibilities.

${ }^{4}$ Ann Rigney, "Cultural Memory Studies: Mediation, Narrative, and the Aesthetic," in Routledge International Handbook of Memory Studies, ed. Anna Lisa Tota and Trever Hagen (London: Routledge, 2016), 68.

${ }^{5}$ Michael Rothberg, Multidirectional Memory: Remembering the Holocaust in the Age of Decolonization (Stanford, CA: Stanford University Press, 2009).

${ }^{6}$ Rothberg, Multidirectional Memory, 3.

${ }^{7}$ Michael Rothberg, "Multidirectional Memory in Migratory Settings: The Case of Post-Holocaust Germany," in Transnational Memory: Circulation, Articulation, Scales, ed. Chiara De Cesari and Ann Rigney (Berlin: De Gruyter, 2014), 123-46, https://doi.org/10.1515/9783110359107.123.

${ }^{8}$ In Rothberg's case, colonization.

${ }^{9}$ Rothberg, Multidirectional Memory, 3.
} 
performance and enables me to analyze how sounding memories of the Nazi period, more recent memories of racist violence and far right terrorism, as well as memories of migrants' experiences, emerge in dialogue.

My research is informed by ethnomusicological methods. I carried out participant observation at approximately fifteen performances of the group between 2015 and $2020 .{ }^{10}$ Performance contexts included commemoration days, festivals, protests, and a people's tribunal. I conducted semi-structured interviews with all active group members: Esther and Joram Bejarano, Kutlu Yurtseven, and Rossi Pennino. ${ }^{11}$ As part of my approach, I further analyze selected songs, paying special attention to the layering of memories.

I will first show how the band foregrounds memories of Nazi persecution and the Holocaust in particular, arguing that through musical means the past is actualized and made present. I will then shift my focus to a second layer of memory work and the group's remembrance of racist attacks and far right terrorism after the German reunification, including the torching of refugee shelters and migrants' homes in the 1990s, the killings perpetrated by the neo-Nazi network NSU in the early 2000s, and recent attacks. I contend that these constitute "moments of danger," 12 which evoke the memory of the Nazi past and facilitate establishing connections and highlighting continuities with regard to racist violence. Focusing on a third layer of the musical memory work, I will examine how the group contributes to the visibility of marginalized memories of migration, especially the so-called Gastarbeiter generation, migrant workers who came to Germany between 1955 and 1973 and helped rebuild the country's economy after WWII. ${ }^{13}$ My analysis shows that the group's commitment to the memory of the Holocaust is at the same time a fight for the memory of the victims of racist violence and a criticism of the marginalization of migrants and their experiences. My inquiry seeks not only to show how songs and performances serve as media of memory, but also to unveil how their multidirectional musical memory work gives rise to new forms of solidarity, and is envisaged as an agent of change and social justice.

\section{Remembering the Holocaust}

In the following, I will inquire into a first layer of the group's multidirectional musical memory work, examining how individual as well as collective memories of the Nazi period and especially the Holocaust are incorporated in and constructed through the group's performance. Central to their performance is its intermediality, that is, the combination of different media, ${ }^{14}$ in this case the fusing of songs, readings, and (political) comments in between the songs. In order to analyze the group's practices of Holocaust remembrance, two medial dimensions are of particular importance: the integration of testimony into the performance, and the reworking of historical antifascist songs.

As shown in the initial vignette, the performance often starts with Esther's reading of an excerpt from her memoirs Erinnerungen (memories). ${ }^{15}$ Esther's narrative usually starts at April 1943 with her deportation

\footnotetext{
${ }^{10}$ Kathleen M. and Billie R. DeWalt, Participant Observation: A Guide for Fieldworkers (Lanham, MD: Altamira, 2010).

${ }^{11}$ Russell Bernard, Research Methods in Anthropology: Qualitative and Quantitative Approaches (Lanham, MD: Rowman \& Littlefield, 2018), 164-5, https://doi.org/10.1086/696167.

${ }^{12}$ Neil Levi and Michael Rothberg, "Memory Studies in a Moment of Danger: Fascism, Postfascism, and the Contemporary Political Imaginary,” Memory Studies 11, no. 3 (2018), https://doi.org/10.1177/1750698018771868.

${ }^{13}$ Asiye Kaya, "Inclusion and Exclusion of Immigrants and the Politics of Labeling," in Migration, Memory, and Diversity: Germany from 1945 to the Present, ed. Cornelia Wilhelm (New York: Berghahn, 2016), 60.

${ }^{14}$ Irina Rajewsky, "Intermediality, Intertextuality, and Remediation: A Literary Perspective on Intermediality," Intermédialités: Histoire et théorie des arts, des lettres et des techniques 6 (2005): 51-2, https://doi.org/10.7202/1005505ar.

${ }^{15}$ Esther Bejarano, Erinnerungen - Vom Mädchenorchester in Auschwitz zur Rap-Band gegen Rechts, ed. Antonella Romeo (Hamburg: Laika, 2013). All translations by the author unless stated otherwise.
} 
to the concentration camp Auschwitz Birkenau at the age of $18 .{ }^{16}$ Singled out as one of those deemed capable of heavy physical labor-young children, older people, those with visible disabilities as well as pregnant women were sent straight to the gas chambers-Esther became part of a column that had to carry heavy rocks, a work that, as she recounts in her reading, would inevitably have led to her death. But her narrative is one of survival. Esther, who grew up as a daughter of a Jewish cantor, had received piano lessons and sung in the synagogue's choir. These musical abilities saved her life. Esther narrates that she volunteered to audition for the newly established camp orchestra in the women's quarter. ${ }^{17}$ Since the orchestra featured no piano, Esther recalls auditioning for accordion, an instrument she had never played before. She passed and was admitted to the orchestra by conductor Sofia Tchaikovska. ${ }^{18}$ Although the conditions of detention improved for orchestra members, Esther describes them as far from decent. Music became a form of forced labor. Cold, hunger, and illness were part of everyday life, as well as the psychological strain of witnessing abuse, torture, and murder. Again, her narrative is a testimony of survival. When her position in the orchestra was threatened by the arrival of a highly proficient accordion player, she played the recorder, and when she fell ill to whooping cough, she learned to play the guitar. Despite the inhumane conditions, she recovered from life-threatening illnesses. After six months in Auschwitz-Birkenau, Esther was sent to the Ravensbrück women's concentration camp, where she became a forced laborer for the company Siemens. In April 1945, Ravensbrück was liquidated, and the inmates were sent on a death march, during which Esther and her friends managed to escape and find shelter among a group of US allies. Esther ends her reading with her experience of the liberation: dancing around a Hitler portrait set on fire with her friends from the concentration camp and playing the accordion.

Esther's narration takes the form of a survivor's testimony. The reading as part of Bejarano and Microphone Mafia's performance passes on autobiographical memories of the Holocaust to subsequent generations, a transfer that can be described in Aleida Assmann's terms as one from neural memory to social memory. ${ }^{19}$ Today, testimonies and readings of life stories are an important part of Holocaust remembrance and education. However, looking back, historian Annette Wieviorka shows that survivors and their accounts were marginalized in the years after WWII and only gained legitimacy with the Eichmann trial in the 1960s, which gave rise to what she terms "the era of the witness."

The rare attempts to bring the memory of the genocide into the public sphere were destined to fail: politicians in every nation were against it; no segment of society demanded it. The Eichmann trial changed matters. At the heart of this newly recognized identity of the survivor was a new function: to be the bearer of history. And the advent of the witness profoundly transformed the very conditions for writing the history of the genocide. With the Eichmann trial, the witness became an embodiment of memory [un homme-mémoire], attesting to the

\footnotetext{
${ }^{16}$ In the case of the event GEGEN DAS VERGESSEN: "Eine falsch eingesetzte Feder machte den Schalter unbrauchbar” held by the Auschwitz Committee on November 7, 2019, on the campus of Hamburg University the reading focused explicitly on her forced labor in Ravensbrück, thus departing from the arrival story in Auschwitz that is a key element of most of Bejarano and Microphone Mafia's performances.

${ }^{17}$ Shirli Gilbert, Music in the Holocaust: Confronting Life in the Nazi Ghettos and Camps (Oxford: Oxford University Press, 2005), 179.

${ }^{18}$ As Gisela Knapp has shown in her study of the women's orchestra of Auschwitz concentration camp, professional female musicians were substantially underrepresented during the Weimar Republic and the Nazi period, since women were stereotyped to be musically unproductive. Accordingly, many women in the orchestra were-like Esther-amateurs (Knapp, Das Frauenorchester in Auschwitz: Musikalische Zwangsarbeit und ihre Bewältigung [Hamburg: Bockel, 1996], 133). ${ }^{19}$ Aleida Assmann, Shadows of Trauma: Memory and the Politics of Postwar Identity (Oxford, UK: Oxford University Press, 2015), 18-22.
} 
past and to the continuing presence of the past. Concurrently, the genocide came to be defined as a succession of individual experiences with which the public was supposed to identify. ${ }^{20}$

As Wieviorka shows, "Survivors, whose stories were avoided during the postwar years, became respectable and respected persons in their very identities as survivors." ${ }^{21}$ Esther, as a survivor of the concentration camps Auschwitz and Ravensbrück, takes on the role of a moral witness and as such "brings together the role of victim and the role of witness." 22 Aleida Assmann states, drawing on Avishai Margalit, "The moral witness does not simply bear a message; in this case, the bearer of the message is the message." ${ }^{23}$ Esther's presence and her reading of the memoirs thus serves a central purpose for the performance. It is crucial in establishing the group's authority and credibility. Kutlu observes that "it is the foundation for everything that follows after. Because they see that the woman who went through all of this is now on stage." ${ }^{24}$ Throughout the performance, Esther's role as a survivor and moral witness provides a key reference point. However, the fact that the reading of the memoirs leaves a lasting impact on the audience is also perceived as a challenge by the artists, who strive to create a positive and familial atmosphere with the onset of the musical performance. ${ }^{25}$

In their music, the group reworks historical antifascist repertoire, including songs from the Nazi ghettos and camps, such as "Tsu eyns, tsvey, dray" or "Mir lebn ejbig," the Italian Resistenza song "Bella Ciao," the Italian socialist/communist song "Bandiera Rossa" but also songs associated with post-WWII resistance against fascism, such as "To sfageio," written by Mikis Theodorakis to address the repression and torture under the Colonels' regime in Greece. ${ }^{26}$ Many of these songs had been part of the repertoire of the Bejaranos' previous band Coincidence, long before the formation of Bejarano and Microphone Mafia. Looking back, Kutlu explains, "We were really lucky that Esther was singing these songs at that time. We took the CD Per la Vita by Coincidence and reworked the songs into rap versions." The songs represent a collective memory of that period, of the fates of those who perished in the Holocaust, and of resistance and defiance in spite of the inhumane living conditions. As Joram points out: "It is the repertoire that fits to describe the time." Through their reworking into new compositions, the songs and their themes are transported into the present moment. ${ }^{27}$

Viewing memory as "the past made present," ${ }^{28}$ I will demonstrate with the help of a selected musical example, the song "Zu eijns, zweij, dreij" from the group's first album Per La Vita (2009), how the past is actualized through the use of rap. The song is based on the resistance song "Tsu eyns, tsvey, dray," ${ }^{29}$ which is itself a rewriting of the "Einheitsfrontlied" (Union Front Song, 1934) originally penned by Berthold

\footnotetext{
${ }^{20}$ Annette Wieviorka, The Era of the Witness (Ithaca, NY: Cornell University Press, 2006), 88-9.

${ }^{21}$ Ibid., 102.

${ }^{22}$ Assmann, Shadows of Trauma, 69.

${ }^{23}$ Ibid., 71.

${ }^{24}$ Kutlu Yurtseven, personal communication, October 8, 2018.

${ }^{25}$ Ibid., October 8, 2018.

${ }^{26}$ In their adaptations the group changes the spellings and occasionally whole titles of the songs. For example, "Bandiera Rossa" becomes "Avanti Populo," and "To sfageio" is translated to "Schlachthof."

${ }^{27}$ I refer to the songs as reworkings or adaptations rather than cover versions. Bejarano and Microphone Mafia's engagement with historical repertoire goes beyond interpreting and reviving previous versions of the songs (on the complicated notion of the "original" see Gilbert, "Buried Monuments: Yiddish Songs and Holocaust Memory," History Workshop Journal 66, no. 1 (2008):123, https://doi.org/10.1093/hwj/dbn026). For the group, the songs rather serve as starting points of the multidirectional musical memory work, in the process of which citations of historical repertoire are combined with and embedded in new lyrics, themes, and musical aesthetics.

${ }^{28}$ Rothberg, Multidirectional Memory, 4.

${ }^{29}$ Spelling according to Shirli Gilbert, Music in the Holocaust, 97.
} 
Brecht (text) and Hanns Eisler (music).$^{30}$ In the summer of 1943, Leyb Rozental, a prolific writer for the ghetto theater in Vilna, Lithuania, wrote the adaptation, which was subsequently sung in- and outside of the ghetto revues. ${ }^{31}$ Rozental's lyrics portray the liquidation of the ghetto. The first three verses depict the insecurities and despair of the ghetto inhabitants, whose lives have not only been turned upside down but who are now also facing deportation. The sound of the steps of the deported signals helplessness: "Each step has its own sound, every path has its own song if you leave and you do not know why." The last verse, on the other hand, can be read as symbolizing hope-the rhythm of the steps changes as the lyrics suggest a future unity of the enslaved, and the steps of the deported now take on a different sound.

In their adaptation, Bejarano and Microphone Mafia combine excerpts from Rozental's lyrics with new rap lyrics. This approach is in many ways representative of the group's songwriting, as Kutlu says, "This was the underlying idea of the whole thing. Taking older texts and reworking them." ${ }^{32}$ In the rap parts, Kutlu and Rossi take on the perspective of individuals rounded up for deportation, voicing their fright and despair. Rossi recounts the writing process:

I simply imagined it [the deportation] figuratively. My rap goes: "Zack, zack in Reih und Glied, mit Sack und Pack auf der Straße aufgestellt, manche waren noch halb nackt” [hurry, hurry, in a row, lined up on the street with sacks and bags, some were still half naked]. I have these images in my head of the liquidation of the ghetto. And do you know where I got these pictures from? Schindler's List, for example. . . And then I tried to write this down. But from my perspective, if I had been there. ${ }^{33}$

The shift to first person perspective is central. "You listen to the song and wonder: How could we write this? You read the theme and then you start writing. You put yourself in the role. ${ }^{" 34}$ Rossi credits the film Schindler's List (1993) as an important influence for his songwriting. In her seminal book Prosthetic Memory, Alison Landsberg has described the potential of cinema for people to "inhabit subject positions and pasts through which they might not themselves have lived and to which they have no 'natural' connection." 35 The process of "suturing" oneself into historical narratives and developing "prosthetic memories" ${ }^{36}$ is clearly visible in Rossi's songwriting approach. The suture and assuming of a role take place not only in the songwriting but also on stage, as Rossi shows: "When performing 'Zu eijns, zweij, dreij' on stage, I am into it." ${ }^{37}$

In their lyrics, the rappers depict the deportation as it unfolds. Since rap is often associated with contemporary social commentary rather than with being a vehicle for historical facts and experiences, ${ }^{38}$ it is likely that listeners will first interpret the lyrics as addressing the present. This is in fact intended by the

\footnotetext{
${ }^{30}$ Jan Knopf, ed., Brecht Handbuch, Vol. 2: Gedichte (Stuttgart: Metzler, 2001), 3-4, https://doi.org/10.1007/978-3-47605609-2. In the summer of 1943, Yiddish writer Shmerke Kaczerginski also drew on the melody for the "Partizaner March" (March of the Partisans), which became a hymn of the Fareynigte Partizaner Organizatsye (United Partisans' Organization FPO) in the Ghetto of Vilna, Lithuania (Gilbert, Music in the Holocaust, 73-4; https://holocaustmusic.ort.org/places/ghettos/vilna/partizaner-marsh/).

${ }^{31}$ Gilbert, Music in the Holocaust, 55-98.

${ }^{32}$ Kutlu Yurtseven, personal communication, August 24, 2018.

${ }^{33}$ Rossi Pennino, personal communication, September 30, 2020.

${ }^{34}$ Ibid.

${ }^{35}$ Alison Landsberg, Prosthetic Memory: The Transformation of American Remembrance in the Age of Mass Culture (New York: Columbia University Press, 2004), 14.

${ }^{36}$ Ibid.

${ }^{37}$ Rossi Pennino, personal communication, September 30, 2020.

${ }^{38}$ E.g., Matthew Oware, I Got Something to Say: Gender, Race, and Social Consciousness in Rap Music (Cham, Switzerland: Springer, 2018), https://doi.org/10.1007/978-3-319-90454-2.
} 
rappers, as Kutlu notes: "Our lyrics transport us into the here and now." 39 In the course of the song, however, the use of key words clearly evokes images of the Holocaust. These include references to the victims: especially "aufgereiht wie Vieh" (lined up like cattle), "Schlachtvieh" (slaughter cattle), and the image of people rushed to line up in the street carrying their belongings, "in Reih und Glied mit Sack und Pack auf der Straße aufgestellt"; the perpetrators: "Schergen" (henchmen), "Mörder" (murderers), "Bestien" (beasts); and the labor and extermination camps: "Züge" (cargo trains) as a symbol for the deportation, and "blauer Dunst steigt in den Himmel" (blue smoke rising) referring to the crematoria. The rappers here clearly make use of images of the Holocaust that are part of collective memory. As Rossi points out, these images are derived from media products, especially Schindler's List, revealing a process that Astrid Erll has described as "remediation":

By the term "remediation" I refer to the fact that especially those events which are transformed into lieux de mémoire are usually represented again and again, over decades and centuries, in different media. What is known about an event which has turned into a site of memory, therefore, seems to refer not so much to what one might cautiously call the "actual event", but instead to a canon of existent medial constructions, to the narratives, images and myths circulating in a memory culture. ${ }^{40}$

Images of the Holocaust are remediated through the lyrics. The example also shows that media productsin this case film—can provide schemata for the representation of the Holocaust, a process Erll has referred to as "premediation." "41

Images of the Holocaust are further evoked through sonic means. Bejarano and Microphone Mafia make use of quotations that serve as auditory signifiers of the deportations. Drawing on Serge Lacasse, Justin Williams distinguishes between autosonic quotations, quoting by sampling from the original recording, and allosonic quotations, quoting the "previous material by way of rerecording or performing it live." ${ }^{42}$ Different types of allosonic quotations can be found in the song. Halfway through the third line of the lyrics "I am looking for wife and child, please tell me where they are"-which itself contains a paraphrasing of Rozental's line "Wu dajn froj, wu dajn kind" — sighs can be identified in the background of the track, sonic representations of the (female) victims of the deportation and the suffering of the deported. The chorus and the outro feature a recurring sample of drum rolls, evoking associations with the military, or roll calls, another image closely associated with the concentration camps. Perhaps most importantly, the beat of the song is itself a signifier of the Holocaust, as Rossi explains: "The heavy beat is supposed to represent the heavy burden that the people carried when they marched, you know, [to] the death camp." ${ }^{43}$ The 122-bpm beat follows a steady eighth notes pattern, in which the stresses fall on the bass drum and snare. Following Rossi's suggestion, these stresses can be interpreted as the slow and heavy steps of the deported.

\footnotetext{
${ }^{39}$ Kutlu Yurtseven, personal communication, August 24, 2020.

${ }^{40}$ Astrid Erll, "Remembering across Time, Space, and Cultures: Premediation, Remediation and the 'Indian Mutiny," in Mediation, Remediation, and the Dynamics of Cultural Memory, ed. Astrid Erll and Ann Rigney (Berlin: De Gruyter, 2009), 111, https://doi.org/10.1515/9783110217384.2.109.

${ }^{41}$ Ibid.

${ }^{42}$ Justin A. Williams, Rhymin' and Stealin': Musical Borrowing in Hip-Hop (Ann Arbor: University of Michigan Press, 2013 ), 3.

${ }^{43}$ Rossi Pennino, personal communication, September 30, 2020, https://doi.org/10.3998/mpub.3480627.
} 


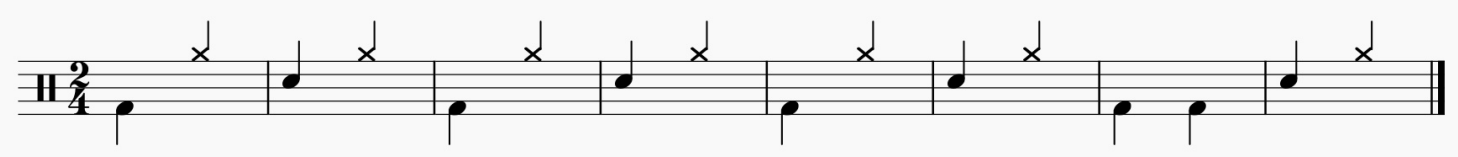

Figure 1: Beat representing the deportation

Rossi's beat picks up a theme already present in Rozental's lyrics, in which the steps of the deported signify despair and, later on, resistance. It thus constitutes an intermedial remediation-from lyrics/language to a sonic representation.

In the chorus, the song most explicitly remediates historical antifascist repertoire. The melody of the chorus follows Eisler's composition, and the lyrics are based on the third verse of Rozental's lyrics, establishing a direct connection to antifascist musical legacies. With regard to the chorus, language and voice further merit attention. It is sung by Esther in Yiddish, the language of the Ashkenazi Jews spoken in different places throughout the Jewish diaspora, but especially Eastern Europe, thus representing the vast geographical dimension of the Holocaust and its victims. The sound of Esther's voice gives away her age, further adding to the layering of temporalities. The song not only combines rap and antifascist repertoire but is also performed by a trans-generational group. Esther's voice signifies the body of the moral witness, imbuing the musical memory work with historical authority.

The remediation of historical repertoire and the actualization through rap and sampling can be found in numerous songs of the group. The use of rap is a conscious choice precisely due to its supposed potential to bring the past into the present. For Esther, music provides an ideal means for political activism and educating people, and she has made use of its potential with her previous groups Siebenschön and Coincidence. The collaboration with the rap artists, however, enables her to reach a wider-and youngeraudience. As Joram says, "With Coincidence we had a predominantly older audience. Coincidence was mainly invited by Jewish communities. Those people came there to listen to the old songs and sing along. That wasn't the point at all. The point is to educate people." 44 This is central to Esther, who describes her motivation: "I want everyone to know what happened. After the Holocaust there was absolutely no disclosure." ${ }^{45}$ The fact that she encountered music as a means of Nazi terror, serving purposes of demoralization, deception, and torture of the victims, as well as entertainment and easing the conscience of the perpetrators, ${ }^{46}$ does not pose an obstacle. She stresses, "Many people ask me if I can still sing after Auschwitz. Or make music. But exactly the opposite is the case! You have to try with all your strength and your knowledge to express what happened in Auschwitz and what kind of horrible ideology fascism is. And this works very well with music." ${ }^{47}$ Accordingly, Bejarano and Microphone Mafia perform in educational contexts including schools and commemoration sites. The group is also frequently invited to perform on commemoration days, such as the International Holocaust Remembrance Day (January 27), Liberation Day (May 8), or commemoration of the November Pogroms (November 9), often euphemistically referred to as "Kristallnacht." While Holocaust memory is one central component of the group's multidirectional musical memory work, it is by far not the sole aspect.

\footnotetext{
${ }^{44}$ Joram Bejarano, personal communication, April 16, 2019.

${ }^{45}$ Esther Bejarano, personal communication, April 21, 2017.

${ }^{46}$ Gisela Knapp, Das Frauenorchester in Auschwitz, 325.

${ }^{47}$ Esther Bejarano, personal communication, April 21, 2017.
} 


\section{Remembering Post-WWII Racist Violence}

Bejarano and Microphone Mafia's Holocaust remembrance not only facilitates remembering the Nazi past but also interpreting post-WWII racist violence in this light. The group's musical memory work gives rise to what Rothberg has described as a dialogical emergence of memories of violent pasts. ${ }^{48}$ In their music, performance, and choice of performance contexts, Bejarano and Microphone Mafia set in dialogue memories of the Holocaust with those of racist violence in the post-WWII era, especially after the German reunification. As Fatima El-Tayeb shows, "The German climate after reunification was increasingly openly racist. Pogroms in the East and murderous arson attacks in the West shook at least parts of the public, but ultimately led to a social shift to the right that made nationalist and racist positions increasingly acceptable." ${ }^{29}$ Most notable are the arson attacks in Hoyerswerda, Rostock-Lichtenhagen, Mölln, and Solingen of the 1990s, and more recently, the bombings and killings by the Neo-Nazi terror network National Socialist Underground (NSU). The NSU was a Neo-Nazi terror organization that was active between 1998 and 2011 and committed several racist murders and bombings between 2000 and 2007, leaving ten people dead, mainly migrants.

From the perspective of memory studies, these incidents can be described as "moments of danger." Drawing on Walter Benjamin's observation that the rise of fascism and Nazism constitutes a "moment of danger" in which memory of enslaved ancestors flashes up, ${ }^{51}$ Neil Levi and Michael Rothberg claim that the present transnational surge of far-right political movements gives rise to a similar "mnemonic flash"-this time of fascism and Nazism itself. ${ }^{52}$ Besides racist attacks that took place shortly after the German reunification in the early 1990s, the attacks of the NSU and recent attacks (e.g., a racist shooting killing ten people in the city of Hanau in 2020) are central "moments of danger" addressed by the group. Examining "moments of danger" in Bejarano and Microphone Mafia's musical memory work, I will show how these are remembered, paying special attention to connections between them and their links to the memory of the Nazi past. In doing so, I aim to show that the fight against postwar racist violence is at the same time also a fight for a marginalized memory.

Bejarano and Microphone Mafia's repertoire not only encompasses songs that are connected to historical antifascist resistances but also includes reworkings of songs written by Microphone Mafia, reflecting their encounters with racist violence. Microphone Mafia's engagement with the theme goes back to the early 1990s. After the German reunification, racist violence did not go unnoticed in the hip-hop scene. It was central for the development of political awareness for many groups, motivating rappers, especially those with migrant backgrounds, to raise their voices. ${ }^{53}$ Microphone Mafia was one of the groups that addressed the racist attacks and their implications. Experiencing the terror slowly encroaching was central in the politicization of the group, as Kutlu recounts:

Rostock-Lichtenhagen, Hoyerswerda, we found it unsettling but for us it was a televised event. We released the song "Stop," which is about the attacks. It came out in 1992, we recorded it at the end of '91. That's when Hoyerswerda and later Rostock-Lichtenhagen happened. But to be

\footnotetext{
${ }^{48}$ Rothberg, Multidirectional Memory, 22.

${ }^{49}$ Fatima El-Tayeb, Undeutsch: Die Konstruktion des Anderen in der postmigrantischen Gesellschaft (Berlin: De Gruyter, 2016), 120-1, https://doi.org/10.14361/9783839430743.

${ }^{50}$ Levi and Rothberg, "Memory Studies in a Moment of Danger."

${ }^{51}$ Ibid., 355-6.

52 Ibid., 356.

${ }^{53}$ Ayla Güler Saied, Rap in Deutschland: Musik als Interaktionsmedium zwischen Partykultur und urbanen Anerkennungskämpfen (Bielefeld: Transcript, 2012), 55-6, https://doi.org/10.14361/transcript.9783839422519.
} 
honest, we weren't personally affected. It was more of an artistic approach. And then the house in Mölln was torched and we thought, oh shit! Those are Turks. Suddenly this felt much closer. Of course, this is ridiculous but that's the way we were, I mean, I was young. When the attack in Solingen happened, it was suddenly in front of our doorstep. ${ }^{54}$

Not only did the attack occur within close physical proximity-Solingen is only a thirty-minute drive from the city of Cologne-but it also unmistakably made clear that the attack was directed at people of Turkish descent and thus received particular attention in the Turkish community. ${ }^{55}$

Bejarano and Microphone Mafia's reworkings of Microphone Mafia's songs addressing these "moments of danger" of the early 1990s can especially be found on the second album of the group, La Vita Continua (2013), in which the band "tried bringing the past fights and struggles into the here and now." 56 A good example is the song "Insanlar" (People), a first version of which had been released on the sampler SOS Deutschland - Stop Faschismus! Stop Rassismus! (1993) and Microphone Mafia's album Vendetta (1996). While music and text of the new version by Bejarano and Microphone Mafia differ-the original version is in Turkish and Bejarano and Microphone Mafia's text predominantly in German, with only one Turkish rap verse - the songs are almost identical content-wise, addressing the torching of migrants' homes and the indifference of wide sections of the population. The lyrics alternate between observations of racist violence ("I see people running away, I see people screaming, I see children with frightened looks on their faces, crying, I see the devil ruling this world right now, I see people cruelly killing each other") and calls to unite for the common struggle against racism and indifference ("Let's move together like a crisis team, Let us see the world from above like on a Ferris wheel, Let us start over, together we are strong, Humanity is what remains on a bad day"). Especially prominent is the theme of indifference towards racist violence: "People are suffering, once again people look the other way." It is not the first time that racist violence is ignored. The line brings back memories of the widespread ignorance of the deportation of the victims of the Nazi regime and people's claims to have been unaware of the concentration camps. The rappers address the listeners directly ("Help to nip hate and anger in the bud") and hold them responsible ("Tell me, are you also of those who prefer to look away?"). The pogroms demonstrated how the "silent majority"-itself not affected by racist violence-contributed to its normalization by ignoring it. ${ }^{57}$ The chorus then calls out those who remain silent. Esther's repetition of the term "insanlar" is followed by Rossi's lines: "Menschen leiden, doch du bist still" ("People are suffering but you remain silent") and "Menschen brennen, doch du bist still" ("People are burning but you remain silent"). As in "Zu eijns, zwej, drej," samples add to reinforcing the image portrayed in the lyrics. The samples of screams at the end of the second chorus (2:31) and in the third verse (2:45) add to the sonic picture of the pogroms.

The attacks of the early 1990s do not constitute the sole "moments of danger" addressed by Bejarano and Microphone Mafia. In 2004, Kutlu encountered another attack that would become central to the group; this time literally in front of his doorstep. On July 9, 2004, a nail bomb detonated in the busy shopping street Keupstraße, right in front of a barber's shop. The attack left 22 people injured and many more traumatized. In 2011, it was revealed that the bomb had been planted by the National Socialist Underground (NSU). ${ }^{58}$

\footnotetext{
${ }^{54}$ Kutlu Yurtseven in Schoop, “Standing up against Discrimination and Exclusion," 207-15.

${ }^{55}$ Çağrı Kahveci and Özge Pınar Sarp, "Von Solingen zum NSU: Rassistische Gewalt im kollektiven Gedächtnis von Migrant^innen türkischer Herkunft," in Den NSU-Komplex analysieren, ed. Juliane Karakayali, Çagri Kahveci, Doris Liebscher, and Carl Melchers (Bielefeld: Transcript, 2017), 37-56, https://doi.org/10.14361/9783839437094-004.

${ }^{56}$ Kutlu Yurtseven, personal communication, October 8, 2018.

${ }^{57}$ El-Tayeb, Undeutsch, 122.

${ }^{58}$ Among them Turks, Kurds, a Greek citizen, and a German police woman.
} 
It is highly unlikely that the choice of the site of the attack was a coincidence. Keupstraße has been stigmatized by the media as an "epitome of a parallel society" 59 and has been referred to as "Little Istanbul" or a "Turkish ghetto," based on an alleged cultural homogeneity ${ }^{60}$ Racist prejudices were deployed and reproduced in the investigations. What happened in Keupstraße is in many ways symptomatic of how cases involving the NSU have been handled by the authorities. As Hanna Soditt and Fiona Schmidt show, allegations by victims' relatives pointing to the right-wing background of the perpetrators were not, or not sufficiently, followed up. Instead, connections to the drug trade, to prostitution or terrorist organizations, such as the PKK, were investigated-without evidence. ${ }^{61}$ The victims of the attacks were further stigmatized by the media through the use of terms like "Döner Morde" (Döner [kebab] murders). ${ }^{6}$ Kutlu, who was himself a resident of Keupstraße at the time of the attack, co-founded the initiative Keupstraße ist überall (Keupstraße is everywhere), to support the victims and to counter the stigmatization: "I know many of the people who live in Keupstraße since my youth. This is why this topic is close to me, also personally. Not just as an activist, as a person, as a human being also. And here also, it is the same mechanisms. The defamation only worked because people tolerated it." ${ }^{63}$

A central instance in Bejarano and Microphone Mafia's memory work addressing the attacks of the NSU and the flaws in the investigations as "moments of danger" is the group's participation in the people's tribunal "Unraveling the NSU Complex," which took place in Cologne from May 17-21, 2017, and was co-organized by Kutlu. The tribunal criticized the state's failure to fight and prevent right-wing terrorism and made the voices of the victims heard. On the first day, Esther gave a short speech, highlighting continuities, among them the lack of trust in the authorities that had once more been revealed:

I say it again and again and will say it in the future: those who fight against the Nazis, unfortunately, cannot rely on the state! I have to shout out loud, for years this tradition has continued in Germany. Whether in front of my boutique, or in Rostock-Lichtenhagen, the authorities do not protect victims but their sources, who are Nazis! ${ }^{64}$

Esther points at the particularly suspicious role of the Federal Office for the Protection of the Constitution (Verfassungsschutz) and their use of informants from the Neo-Nazi scene in the NSU investigations. The tribunal's initiative resonates with readings of the NSU investigations that highlight suspicions of "collusion," ${ }^{65}$ i.e., "the willful failure to keep records, the absence of accountability, the withholding of intelligence and evidence, and the extreme of agents being involved in murder." ${ }^{66}$ Drawing attention to these processes, the tribunal called into question a predominant pattern in the explanation of right-wing violence in Germany: the assumption that these acts are committed by individual perpetrators. ${ }^{67}$ It is quite telling that

\footnotetext{
${ }^{59}$ Güler Saied, Rap in Deutschland, 83, 128-31.

${ }^{60}$ Ibid., 131-2. This view not only ignores the de facto cultural diversity—not least among the Turkish population itself-and structural transformations of the neighborhood, but also reveals the ignorance of the neglect of the city quarters in question, blaming of the inhabitants for the precarious situation and the marginalization of the areas (ibid., 131-132). The stigmatization is actually a continuation of a former marginalization of the street—formerly termed Wolfsstrasse-that dates back to its time as a workers' quarter (ibid., 132).

${ }^{61}$ Hanna Soditt and Fiona Schmidt, "Staatliche Kollusion im NSU-Komplex," in Den NSU-Komplex analysieren, ed. Juliane Karakayali, Çagri Kahveci, Doris Liebscher, and Carl Melchers (Bielefeld: Transcript, 2017), 191-208, https://doi.org/10.14361/9783839437094-012.

${ }^{62}$ See for example https://www.cicero.de/innenpolitik/nsu-mordserie-den-medien-wie-aus-opfern-taeter-wurden/58728.

${ }^{63}$ Kutlu Yurtseven, personal communication, August 10, 2018.

${ }^{64}$ Esther Bejarano, speech at NSU-Tribunal, May 17, 2017.

${ }^{65}$ Soditt and Schmidt, "Staatliche Kollusion," 93-4, 201.

${ }^{66} \mathrm{http}: / /$ news.bbc.co.uk/nol/shared/spl/hi/northern_ireland/03/stephens_inquiry $/ \mathrm{html} /$ default.stm

${ }^{67}$ El-Tayeb, Undeutsch, 125. This pattern stands in stark contrast to terrorism from "marked" groups, e.g., Muslims, where group responsibility and ultimately group characteristics are foregrounded (ibid.).
} 
it was the suicide of NSU members Uwe Mundlos and Uwe Böhnhardt after a bank robbery and the resulting police chase that led to the unmasking of the NSU, not the investigations themselves. Instead of shedding light on structures of the far right and preventing crimes, inquiries have shown that state money has supported right-wing activities, possibly the NSU itself. ${ }^{68}$ Soditt and Schmidt show that in the trial, connections and activities were covered up, using the pretext of protecting sources. ${ }^{69}$ The official narrativethat the core group consisting of Mundlos, Böhnhardt, and Beate Zschäpe was supported by a very small circle after it went underground in 1998-is reflected in the sentences. While the surviving core member Zschäpe was sentenced to life imprisonment in $2018,{ }^{70}$ only four people were sentenced to prison for assisting the NSU. ${ }^{71} \mathrm{Up}$ to the present day, the number of people who were part of the network remains unknown.

Like Esther, Kutlu sees a continuity from the time of National Socialism to today:

This is the red thread. Look, the war ended in 1945. There was no denazification. The Federal Office for the Protection of the Constitution is populated by Neo-Nazis, National Socialists. This had an impact on politics. For decades. In dealing with migrants, with political dissidents.... And the pogroms after the fall of the wall, at the beginning of the 1990s, the NSU. There is a red thread there. Also in our everyday life. Because the mechanisms are identical: remaining silent, hiding, not standing up. ${ }^{72}$

Through their participation in the tribunal, the group establishes connections between the Nazi past and the present. This is done specifically through Esther's speech, which establishes analogies and closes with her announcement that "the NSU tribunal is now part of my revenge on the Nazis," but also musically through the performance of the songs "Insanlar," "Mir leben ejbig," and "Schir Schalom." The group raps against old and new Nazis, combining songs that signify resistance to the Nazi regime and rejection of postwar violence and imagine a peaceful present and future. The group makes explicit that racist ideologies are not a thing of the past and neither are bystanders who remain silent.

The multidirectional connection of racist violence after WWII to the Nazi crimes is not only to be found in the context of the tribunal but is a regular part of their performances. Esther's reading of her memoirs and her role as a survivor and moral witness are central, as Kutlu illustrates:

Esther has an important role here: she says that you are not responsible for what happened. You are only guilty if you forget. And people draw parallels. When Esther reads from her memoirs, people think, "Wow, that's happening too!" In parts, of course, right now. . . There is always the connection to the present. Hey guys, we are not there yet but if we are not careful, it can happen again. And that's a completely different approach, without you blaming people or making them feel guilty. You're holding them accountable. And yourself as well. ${ }^{73}$

The group aims to hold people responsible_not least through highlighting "moments of danger" and the suggesting of historical analogies—a process in which the Nazi past and the Holocaust serve as a key reference point. Djouaria Ghilani et al. state that "structurally speaking, analogies are based upon a two-term relationship: a known, past event (i.e., the source) linked to an unfamiliar, current event ..., which is seen

\footnotetext{
${ }^{68}$ Soditt and Schmidt, "Staatliche Kollusion," 201.

${ }^{69}$ Ibid., 199-200.

${ }^{70}$ https://www.tagesspiegel.de/themen/rechtsextremismus/nsu-prozess-zehn-liter-benzin-verursachten-explosive-wolke-inzwickauer-wohnung/9336170.html.

${ }^{71}$ Matthias Quent, Rassismus, Radikalisierung, Rechtsterrorismus, 2nd ed. (Weinheim, Germany: Beltz, 2019$), 16-7$.

${ }^{72}$ Kutlu Yurtseven, personal communication, August 10, 2018.

${ }^{73}$ Kutlu Yurtseven, personal communication, August 10, 2018.
} 
as similar in some respects to the first." ${ }^{74}$ Historical analogies can have different effects: They can represent a current and unknown situation by anchoring it in the familiar, can help define the social roles of current actors, can influence decision-making, and can provide a means to persuade others of a message. ${ }^{75}$ As a type of "black-and-white" event, the use of the Holocaust as a historical analogy is in a special position to powerfully evoke morality. ${ }^{76}$ Further, "the expertise of the analogizer may be crucial for lending credibility to such a claim." Es7 Esther Bejarano's role as a witness and survivor lends special authority here, not only testifying to Nazi crimes but to recent instances of racist violence connected via analogy. Seen in this light, the evocation of Nazism through highlighting of continuities serves as a warning, a "Never Again" that "projects the catastrophes of the past onto the future." "

The group's fight against racism is also explicitly one for the memory of racist violence. The "single perpetrator hypothesis is not only symptomatic for dealing with acts that are relatively well-anchored in national memory, such as the attacks in Mölln and Solingen, but also explains above all the lack of memory of other, similar events." ${ }^{79}$ Victims of racist violence often do not have a place in official collective memory, or their memory is relegated to the margins. ${ }^{80}$ It is often self-organized grassroots activism that sets out to save memories of racist violence from oblivion. ${ }^{81}$ Bejarano and Microphone Mafia's multidirectional musical memory work constitutes such a form of "bottom-up" activism. Most recently, the group has supported the initiative Herkesin Meydani (everyone's square), ${ }^{82}$ which fights for the memory of the NSU attack in Keupstraße. The initiative calls for the establishment of a memorial square, serving as a meeting place for the community and an educational site against racism. The design by artist Ulf Aminde features an installation of virtual walls that people can engage with via a smartphone app and invites the contribution of individual multimedia materials. Private investors who own the plot on which the memorial is planned have so far impeded its establishment. On September 13, 2020, the group performed the corner of Keupstraße and Schanzenstraße as part of a series of music performances that set up a temporary Herkesin Meydani to raise awareness for the initiative and its challenges, highlighting the need for a permanent physical space of remembrance.

\footnotetext{
${ }^{74}$ Djouaria Ghilani, Olivier Luminet, Hans-Peter Erb, Christine Flassbeck, Valérie Rosoux, Ismee Tames, and Olivier Klein, "Looking Forward to the Past: An Interdisciplinary Discussion on the Use of Historical Analogies and Their Effects," Memory Studies 10, no. 3 (2017): 275, https://doi.org/10.1177/1750698017701609.

${ }^{75}$ Ibid., 278-81.

${ }^{76}$ Ibid., 279.

${ }^{77}$ Ibid., 281.

${ }^{78}$ Alejandro Baer and Natan Sznaider, Memory and Forgetting in the Post-Holocaust Era: The Ethics of Never Again (London: Routledge, 2017), 5, https://doi.org/10.4324/9781315616193.

${ }^{79}$ El-Tayeb, Undeutsch, 124-5.

${ }^{80}$ Examples of the fact that Neo-Nazi terror remains widely ignored and is not remembered are visible in the oblivion of an early arson attack on a refugee shelter in Hamburg in 1980 by Neo-Nazi group Deutsche Aktionsgruppe that killed two people, or the Neo-Nazi attack on the Munich Oktoberfest in 1980, where thirteen people died. In Solingen, a planned memorial in the city center was relegated to the outskirts. For a history of racist violence in Germany and the marginalization of its memory, see Kahveci and Sarp, "Von Solingen zum NSU," 44-51.

${ }^{81}$ The NSU tribunal and the Möllner Rede “im Exil” are just two examples.

${ }^{82}$ See https://mahnmal-keupstrasse.de.
} 


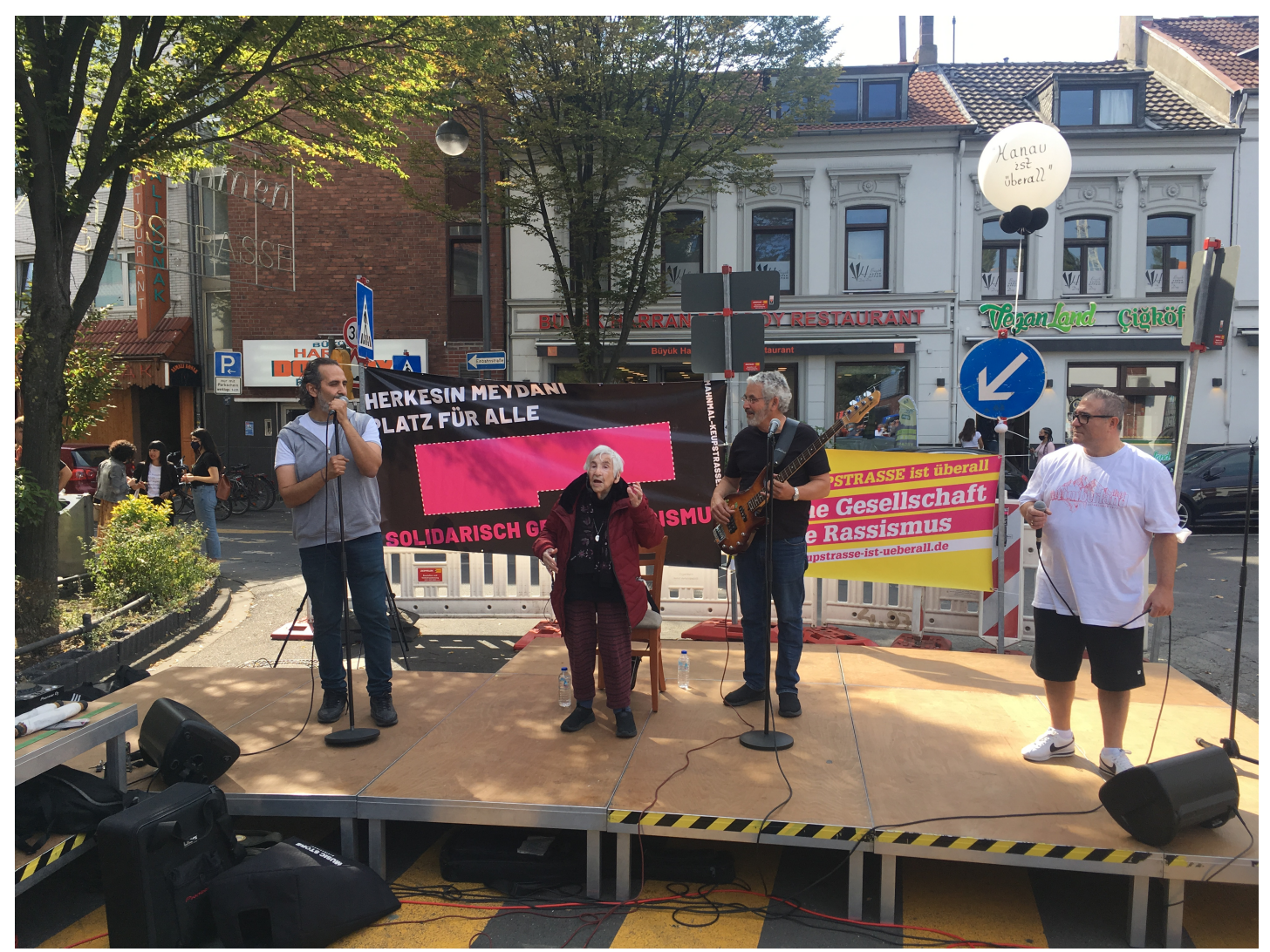

Figure 2: Bejarano and Microphone Mafia performing for the initiative Herkesin Meydani (Photo: Monika E. Schoop)

Bejarano and Microphone Mafia's multidirectional musical memory work also addresses very recent attacks, pointing to continuities of racist violence. "The fate of those murdered by the NSU is currently reappearing in the right-wing violence, the arson attacks on refugee shelters, the PEGIDA marches, the AfD election successes and the widespread indifference in German society. ${ }^{~} 83$ In the case of the performance at Herkesin Meydani, a connection to a racist attack in the city of Hanau is made through the inscription on a balloon (see picture, upper right-hand corner).

Bejarano and Microphone Mafia's multidirectional musical memory work demonstrates that racist ideologies were not an atypical exception of Nazi Germany that ended with WWII. The group highlights continuities through "moments of danger" and establishes historical analogies to the Nazi past, which provides a moral reference point. Their memory work shows the need to acknowledge racist violence as a pressing structural problem that permeates society.

\section{Remembering Migration}

The multidirectional musical memory work of Bejarano and Microphone Mafia encompasses a third layer. Looking back at the history of Microphone Mafia, Kutlu notes: "Our music has always been memory

\footnotetext{
${ }^{83}$ Kahveci and Sarp, "Von Solingen zum NSU," 39. PEGIDA, short for Patriotic Europeans against the Islamization of the Occident, is a far-right and anti-Islam movement founded in Dresden in 2014. The AfD, short for Alternative for Germany, is a German far-right political party founded in 2013, which has steadily gained seats in federal parliaments as well as the Bundestag in the past years.
} 
work also. Remembering migration and what this meant for our lives." ${ }^{84}$ Since its inception, Microphone Mafia has been well known for addressing migrants' experiences in Germany, experiences that also have become part and parcel of Bejarano and Microphone Mafia's memory work. Kutlu and Rossi are themselves children of migrants who came to Germany in the 1950s and 1960s_-a generation of workers that frequently has been referred to as Gastarbeiter (guest workers). ${ }^{85}$ To address the labor shortage after WWII, Germany concluded recruitment agreements with several countries, including Italy (1955), Spain and Greece (1960), Turkey (1961), Morocco (1963), Portugal (1964), and Yugoslavia (1968). ${ }^{86}$ Recruitment was terminated in 1973, when the economy experienced a substantial downturn. ${ }^{87}$ Labor migration models such as the Gastarbeiter symbolize specific perceptions of migrant labor forces ${ }^{88}$ Gastarbeiterwere assumed to be shortcontract workers, who would eventually return to their countries of origin and were thus subject to a policy of non-integration. ${ }^{89}$ Many migrant workers, however, decided to stay in Germany. They saw themselves facing structural exclusion and were subject to labeling strategies that sought to depict them as "foreign," "incompatible," or as "problems" - stigmatizations that extended to the second generation. ${ }^{90}$ When hip-hop spread in Germany in the 1980s, the question of how to "motivate" Gastarbeiter to leave the country predominated in political debates, clearly visible in the implementation of a scheme by chancellor Helmut Kohl that promised financial rewards for those willing to "return." ${ }^{91}$ Experiences of exclusion and issues of belonging of the first-generation migrants and their children gained prominence in public and political discourses. ${ }^{92}$ In this context, migration and integration also became key themes in German hip-hop. ${ }^{93}$

Like the memory of racist violence, memories of migration constitute a marginalized memory, largely neglected by institutional archives and museums. ${ }^{94}$ This is rooted in the fact that Germany's status as a "country of immigration" was not officially acknowledged until $2005,{ }^{95}$ and remains contested in public discourse up to the present day. Research has shown that music, however, has the potential to make

\footnotetext{
${ }^{84}$ Kutlu Yurtseven, personal communication, August 10, 2018. Memory is explicitly addressed in the Microphone Mafia song "Denkmal" (memorial), in which Kutlu addresses the lack of acknowledgement of and calls for respect for the work and experiences of the Gastarbeitergeneration (see Güler Saied, Rap in Deutschland, 86-7).

${ }^{85}$ The term Gastarbeiter replaced the term Fremdarbeiter (foreign worker), which had been used in Nazi Germany. (Güler Saied, Rap in Deutschland, 144)

${ }^{86}$ Kaya, "Inclusion and Exclusion of Immigrants," 59-60.

${ }^{87}$ Ibid., 62.

${ }^{88}$ Ibid., 60.

${ }^{89}$ Ibid., 61.

${ }^{90}$ El-Tayeb, Undeutsch, 164. Kaya, "Inclusion and Exclusion of Immigrants," 63. It has to be noted that Germany has applied different integration measures and labeling strategies for different immigrant groups throughout its history. A "politics of sameness and difference" has for example led to a preferential treatment of ethnic German resettlers, in contrast to "guest workers," resulting in a divergent treatment and experience (Kaya, "Inclusion and Exclusion of Immigrants," 57-60).

${ }^{91}$ Cornelia Wilhelm, "Introduction: Migration, Memory, and Diversity: Germany from 1945 to the Present," in Migration, Memory, and Diversity: Germany from 1945 to the Present, ed. Cornelia Wilhelm (New York: Berghahn, 2016), 2, https://doi.org/10.2307/i.ctvswx6wf.5.

${ }_{92}$ Güler Saied, Rap in Deutschland, 282.

${ }^{93}$ Ibid., 119. Güler Saied states that for many groups, ethnic affiliation did not play a role, but they instead took a "lived multiculturality" for granted, as was also the case for Microphone Mafia (70, 271-2). The practice of multilinguality was accordingly an everyday lived practice rather than a conscious artistic concept $(225,282)$.

${ }^{94}$ Wilhelm, "Introduction: Migration, Memory, and Diversity," 7; and Dietmar Osses, and Katarzyna Nogueira, "Representations of Immigration and Emigration in Germany's Historic Museums," in Migration, Memory, and Diversity: Germany from 1945 to the Present, ed. Cornelia Wilhelm (New York: Berghahn, 2016), 158, https://doi.org/10.2307/i.ctvswx6wf.11.

${ }^{95}$ Kaya, "Inclusion and Exclusion of Immigrants," 61.
} 
marginalized memories of migration audible. ${ }^{96}$ Bejarano and Microphone Mafia's multidirectional musical memory work again follows a "bottom-up" approach that contributes to the visibility of marginalized memories. A good example is the song "Wann jeiht der Himmel widder op" (When will the sky rise again), an adaptation of a song originally written and performed by the Cologne-based band De Höhner (1990). Rossi recalls that listening to the song, he immediately made a connection to his family memories:

I really wanted to do this song because this song "Wann jeiht der Himmel widder op" by De Höhner begins: "On the way to the city, on the beautiful promenade, I saw a man who had obviously just arrived. Black hair, an old jacket, a cardboard box and a sack, which probably contained all his belongings." ${ }^{97}$ This is my father, how he came in by train from Naples in 1958. With a cardboard box, his clothes, and he couldn't speak a word of German. My father used to tell us that he had to undress naked—and back then that was a time when you were ashamedin front of a German doctor, almost like Gestapo and stuff, in barracks. When I heard this song for the first time, it gave me goosebumps. ${ }^{98}$

The first verse of the song by De Höhner narrates the encounter with a migrant worker, drawing on stereotypical images of collective memory: A man with black hair, carrying a few belongings. ${ }^{99}$ The migrant worker has just arrived in Germany, feels lost and does not know where he belongs. In the refrain he asks the question: "When will the sky rise for me? When will the sun shine for me? Aren't we all brothers?" In the rendition by Bejarano and Microphone Mafia, Rossi takes the fairly general and stereotypical depiction of the migrant worker, and turns it into the story of his father and his migration to Germany:

Private videos from the last vacation in Sorrento

Tearing eyes, goosebumps, time running out

40 years in Cologne, a life between heaven and hell

You accept it, whatever the cost

To be king once, to defend your kingdom

You cannot understand the words that offend you

The question why

Staring into a void, as if your whole life was your personal teacher

Without a chance of getting a master craftsman's diploma

While the city slept, you walked through the alleys with dustpan and broom

Suddenly there is neither forward nor back nor here and now.

When will the sky rise for me?

Rossi reworks family memories into music. His description of the lyrics as "memories—or what should not be" 100 shows that these memories are not positive. The story in many ways tells of experiences common to migrant workers of his father's generation. The short-term immigration policy focused solely on labor, intentionally ignoring the migrant workers' "cultural and immigration" needs from the very start. ${ }^{101}$

\footnotetext{
${ }^{96}$ Pinar Güran-Aydin and Tia DeNora, "Remembering through Music: Turkish Diasporic Identities in Berlin," in Routledge International Handbook of Memory Studies, ed. Anna Lisa Tota and Trever Hagen (London: Routledge, 2016), 233-46; Rosa Reitsamer, "Not Singing in Tune: The Hor 29 Novembar Choir and the Invention of a Translocal Do-It-Yourself Popular Music Heritage in Austria," Popular Music and Society39, no. 1 (2016): 59-75, https://doi.org/10.1080/03007766.2015.1061347.

97 “Op dem Wäch in de Stadt op der schönen Promenad, soh ich ne Mann un der kom wohl jrad eets ahn. Schwatze Hoor ahle Jack, Pappkarton un ne Sack, in dem woore wohl sing janze Sache drin."

${ }^{98}$ Rossi Pennino, personal communication, September 30, 2020.

${ }^{99}$ While the majority of migrant workers were in fact male, between 1960 and 1973 female workers constituted 30\% of the foreign workforce (Kaya, "Inclusion and Exclusion of Immigrants," 60).

${ }^{100}$ Rossi Pennino, personal communication, September 30, 2020.

${ }^{101}$ Kaya, "Inclusion and Exclusion of Immigrants," 62.
} 
The workers mainly carried out piecework, shift work, and assembly line production, which did not require an apprenticeship, let alone a university education. ${ }^{102}$ The structural non-integration approach remained in place after the termination of labor recruitment in 1973. Subject to "politics of difference," 103 they faced institutionalized discrimination and structural exclusion. Many first-generation migrants did not acquire a higher level of the German language and faced a lack of educational opportunities and professional advancement, as addressed in Rossi's lyrics: "You cannot understand the words that offend you," "Without a chance of getting a master craftsman's diploma," and "you walked through the alleys with dustpan and broom." Rossi paints the picture of a person torn between two worlds, two places that simultaneously signal belonging and exclusion: Sorrento, the place of departure and presumed home, which is only visited on vacation as a tourist, and Cologne, where the father is able to make a living but is faced with exclusion, a story of failed integration. The structural exclusion and discrimination of immigrants are not specific to the treatment of the Gastarbeiter generation. Cornelia Wilhelm shows that labeling strategies, framing immigrants as "other" and "foreign" to a perceived homogeneous German cultural (and during the period of National Socialism even racial) identity, have been a central component in the building of a German identity ever since Germany's founding as a nation state. ${ }^{104}$

Rossi's and Kutlu's family histories show the extent to which their parents had internalized the narrative that they would return to Italy or Turkey one day. Rossi recounts, "My father wanted to stay here for five years. Then he wanted to go back to Italy. But this never happened, because we here in Germany, we had a completely different perspective to earn a living." Kutlu's family history shows striking parallels:

We actually had a packed suitcase in our apartment. This was the first suitcase we wanted to go back with, well that at least my parents wanted to go back with. So, you never really made yourself at home here, also mentally because you always thought that you would go back one day. It only stopped when I graduated from high school, when my brother married and my nephew was born. That's when it occurred to everybody that there will be no going back and that everything was nothing but an illusion..$^{105}$

Non-immigration policies caused insecurities for the second generation. As Asiye Kaya notes, "Most of the second generation inherited the experience of marginalization, non-recognition, and exclusion, as well as the structural non-integration in German institutions based on the given social political conditions, particularly in the 1970s and 1980s." ${ }^{106}$ It is in the second verse of the song that the rappers-in this instance Kutlu—shift the perspective and reflect on their own personal experiences as second-generation migrants. Again, the theme of belonging and being torn between two cultures is central: "Since childhood I have experienced the daily cultural rollercoaster / Walking over the doorstep felt like crossing a border to me / I have mastered balancing between street and home." The experience of growing up as a child of immigrant workers is described as navigating between two worlds. Kutlu recalls, "At home, you had to follow the Turkish rules. Outside, you had to be German. However, you never fully met the expectations of either culture. Someone would always tell you, you don't fully belong, there is something wrong with you. ${ }^{~} 107 \mathrm{He}$ also shows that for youths with a so-called migrant background, rap became a medium to articulate

\footnotetext{
${ }^{102}$ Güler Saied, Rap in Deutschland, 144.

${ }^{103}$ Kaya, "Inclusion and Exclusion of Immigrants," 60.

${ }^{104}$ Wilhelm, "Introduction: Migration, Memory, and Diversity," 1.

${ }^{105}$ Kutlu Yurtseven in Schoop, "Standing up against Discrimination," 208.

${ }^{106}$ Kaya, "Inclusion and Exclusion of Immigrants," 64. An example for continued structural exclusion are Kutlu's and Joram's negative experiences with the German school system.

${ }^{107}$ Kutlu Yurtseven in Schoop, "Standing up against Discrimination," 208.
} 
experiences of stigmatization and exclusion. ${ }^{108}$ "And then rap came to Germany. A musical style informed by black people, by Hispanics. You only needed a piece of paper and a beat or beatboxing, and you were set. It does not matter where you're from, which religion you are and whether there is a way back or not."109 These experiences of exclusion resonate up to the present day: "Not knowing where you are from is still part of us. And it's our task to make sure that our kids do not experience this anymore."110

While Microphone Mafia's version differs from De Höhner's song through an almost complete rewriting of the lyrics, the two share similarities. The second verse picks up another theme present in the original lyrics. De Höhner's second verse is an introspective account of the first-person narrator, sparked by the encounter with the migrant worker: "On the way to the city, on the beautiful promenade, I realized we waited far too long. Nazi-slogans everywhere, bare fear gripped me. We waited far too long, and did not speak up. Brown clouds over land, yesterday David, today the asylum seeker." An implicit connection between the time of National Socialism—the image of "David" can be seen as representing the Jews and the Holocaust-and contemporary racism towards migrants, especially asylum seekers and a rise of NeoNazism, is made through the color brown, the color of the uniforms of the Nazi paramilitary group SA. Bejarano and Microphone Mafia pick up the image of the "brown clouds," representing the Nazi legacy. Here, however, the first-person narrator is himself subject to defaming labeling and exclusion: "But I was quickly pushed into the role of 'Kanake,' People asked me since when I lived here, And this was immediately followed by the question, when I would leave again." 111 He has to justify his belonging: "I live here, I learn here, I teach here, I suffer here, I belong here, I am not a stowaway" and he is "targeted by populists who say we are not integrated." The line "We did not draft the Foreign Nationals Act" addresses the fact that the children of migrant workers found themselves in a precarious legal situation due to the descent-based (jus sanguinis) understanding of German citizenship, which denied them German citizenship. ${ }^{112}$ Bejarano and Microphone Mafia criticize the citizenship and immigration laws for reproducing inequality on the legal level. Kaya states, "the rigid naturalization law and the denial about Germany being a country of immigration kept access to citizenship out of reach for non-ethnic German and non-European immigrants." ${ }^{113}$ It was not until 1999 that pressure from the European Union initiated the shift to a civic rights-based citizenship (jus soli) model, however, still not without restrictions. ${ }^{114}$

The song shows trajectories of discrimination and exclusion-from the Gastarbeitergeneration to the second generation. It even stretches further back, evoking images of the Nazi past as a looming shadow cast by the "brown clouds." The connection to the Nazi past is further solidified through Esther's participation. The song follows the pattern of Esther singing the refrain and Kutlu and Rossi rapping. As in the previously analyzed songs, Esther takes on the role of a moral witness, establishing a connection between the time of National Socialism and the present.

Bejarano and Microphone Mafia's multidirectional memory work also addresses current migration flows. As Joram explains, political comments in between the songs constitute an important part of Bejarano and Microphone Mafia's memory work: "Before the show, we agree upon the messages we want to convey

\footnotetext{
${ }^{108}$ Güler Saied, Rap in Deutschland, 86.

${ }^{109}$ Kutlu Yurtseven in Schoop, "Standing up against Discrimination," 208-9.

${ }^{110}$ Ibid., 209.

${ }^{111}$ Kanake is a derogatory term used to describe immigrants, mostly of south European, Turkish, North African, or Middle Eastern descent.

${ }^{112}$ Kaya, "Inclusion and Exclusion of Immigrants," 64.

113 Ibid., 64.

${ }^{114}$ El-Tayeb, Undeutsch, 157. Kaya, "Inclusion and Exclusion of Immigrants," 65.
} 
to the audience... . You can always refer to what's happening here and now, in terms of politics." A prominent topic addressed by the group in the performances I attended was forced migration and its connection to ongoing wars and the export of weapons from the European Union. In doing so, the group also criticizes what El-Tayeb has referred to as Europe's "internalistic narrative," an "inward-looking progress narrative" that portrays Europe as independent, ignoring the continent's connection with the rest of the world and a shared history. ${ }^{115}$ As such, Europe is seen as threatened by seemingly external crises. As the right-wing extremist narrative of migration as a threat has rapidly gained momentum in the past years, it is especially the influx of refugees which has been framed as such a crisis. ${ }^{116}$ In the case of Germany, this view of immigrants as alien and as a threat has a long history and can be observed during and after the Nazi period. ${ }^{117}$ Bejarano and Microphone Mafia's performances draw attention to the contradiction between Europe's image as the home of human rights and its refusal to take responsibility for the thousands of human beings dying in their attempt to reach the continent, especially when crossing the Mediterranean Sea. ${ }^{118}$ The memory work raises attention for the underlying structures of inequality, unraveling poverty, and flight as products of a "global economic system, from which the West profits disproportionately." refugees, it draws attention to those whose lives are not only not considered worth protecting, but also not deemed worthy of being mourned and remembered. ${ }^{120}$

Experiences of exclusion and discrimination are not only central themes in songs and performances. They are also key to the formation of a bond between the group members, as Rossi's reflections on his experiences with discrimination show:

Whenever my father had to fill in forms at the bank, I accompanied him. And then people give you these looks: "Can't your father do that himself?" No, he can't. And then you hear them murmuring: "He does not speak German; he has been here for such a long time!" ... Or when I had my first girlfriend, she was also German. We were sitting next to each other on the S-Bahn and she leaned her head on my shoulder. I heard from a distance: "Poor Germany." Stories like this. That's what we encountered. And that's why I think that we have a say.

Establishing connections between experiences of second-generation immigrants and Nazi persecution prompts Rossi to stress that he by no means intends to relativize the Holocaust,

I don't want to compare the history of the Holocaust to [issues of] immigration and integration. That was a different time. It was a million times worse. But what happened to me with integration, what happened to foreigners. That was also cruel, horrible. We can sympathize with what such a person must have gone through. ${ }^{121}$

The question whether the Holocaust constitutes a singular and incomparable event-central to the Historikerstreit of the 1980s-clearly resonates in Rossi's statement, showing the challenges of multidirectional memory work, which obviously requires a clear distancing from Holocaust relativization.

Different experiences of racism and common goals to fight racism and to remember its victims have provided interfaces for the formation of new alliances. This connection had not existed from the very start,

\footnotetext{
${ }^{115}$ El-Tayeb, Undeutsch, 45.

${ }^{116}$ Ibid., 208.

${ }^{117}$ Wilhelm, "Introduction: Migration, Memory, and Diversity," 1.

${ }^{118} \mathrm{cf}$. El-Tayeb, Undeutsch, 55.

${ }^{119}$ El-Tayeb, Undeutsch, 57.

${ }^{120}$ Kahveci and Sarp, "Von Solingen zum NSU," 45.

${ }^{121}$ Rossi Pennino, personal communication, September 30, 2020.
} 
as Joram and Esther were first very skeptical towards the collaboration. ${ }^{122}$ Rather, it has evolved through the group's multidirectional memory work, providing evidence for Rothberg's claim that "when the productive, intercultural dynamic of multidirectional memory is explicitly claimed, . . it has the potential to create new forms of solidarity and new visions of justice." ${ }^{23}$ Today, the group looks back on a twelve-year collaboration, which has exceeded fighting for a common cause, as Joram notes: "This has actually grown into a very dear family. That connects us." 124

\section{Conclusion}

Employing the concept of multidirectional musical memory work, this article has shown how Bejarano and Microphone Mafia interweave individual and collective memories of the Nazi past and the Holocaust with those of racist attacks and far right terrorism, as well as marginalized memories of migration to Germany and more recently the European Union. Their multifaceted musical memory work makes use of remediations of historical antifascist repertoire, rap, and samples, which go hand in hand to construct musical images of racist violence and exclusion. As inherently intermedial, the group's multidirectional memories emerge through the interplay of music, testimony, and political commentary. The analysis has shown that in the memory work of Bejarano and Microphone Mafia, memories of the Nazi past and the Holocaust serve as central reference points, providing an anchor for historical analogies evoked by "moments of danger" and the highlighting of continuities of racist violence. The Nazi past serves as a warning, a reminder of atrocities that should happen "never again." Of particular importance is the role of Esther as a moral witness, which imbues the memory work with authority. The inquiry has, however, not only shown how memory of the Holocaust can provide a vehicle through which other histories of violence and marginalization can be articulated; it has also shown how remembrance of more recent instances of racist violence can provide avenues for remembering the Nazi past as well, as the example of the NSU tribunal and Herkesin Meydani show.

Transcultural, cross-generational, and interreligious, the multidirectional musical memory work has given rise to new forms of solidarity that move beyond fixed group identities. Esther, the Jewish concentration camp survivor, her son Joram, who was born in Israel and came to Hamburg as a child, Kutlu, the son of Muslim migrant workers from Turkey, and Rossi, the son of Catholic Italian migrant workers, remember for the present and future. Their music and performances give rise to visions of justice-literally as in the case of the NSU tribunal, but also figuratively, imagining a society without racist violence and exclusion. These visions are not losing their relevance in the face of calls for a turn towards the positive aspects of German history and continuing racist violence. On the contrary, as the image of history as repeating itself is becoming all the more prominent, the need to continue rapping against old and new Nazis is perhaps more important than ever.

In memory of Esther Bejarano (December 15, 1924-July 10, 2021), who died shortly after this article was completed.

\footnotetext{
${ }^{122}$ Joram Bejarano, personal communication, April 16, 2019.

${ }^{123}$ Rothberg, Multidirectional Memory, 5.

${ }^{124}$ Joram Bejarano, personal communication, April 16, 2019.
} 


\section{List of Interviews}

Esther Bejarano. Interview. April 21, 2017.

Esther Bejarano. Speech at NSU Tribunal. May 17, 2017.

Kutlu Yurtseven. Interview. August 24, 2018.

Kutlu Yurtseven. Interview. October 08, 2018.

Joram Bejarano. Interview. April 16, 2019.

Rossi Pennino. Interview. September 30, 2020.

\section{Bibliography}

Assmann, Aleida. Shadows of Trauma: Memory and the Politics of Postwar Identity. New York: Fordham University Press, 2016.

Baer, Alejandro, and Natan Sznaider. Memory and Forgetting in the Post-Holocaust Era: The Ethics of Never Again. London: Routledge, 2017. https://doi.org/10.4324/9781315616193.

Bejarano, Esther. Erinnerungen: Vom Mädchenorchester in Auschwitz zur Rap-Band gegen rechts. Edited by Antonella Romeo. Hamburg: Laika, 2013.

Bernard, Russell. Research Methods in Anthropology: Qualitative and Quantitative Approaches. Lanham, MD: Rowman \& Littlefield, 2018. https://doi.org/10.1086/696167.

De Höhner. "Wann jeiht dr Himmel widder op.” Leider gut. EMI, 1990.

DeWalt, Kathleen M., and Billie R. DeWalt. Participant Observation: A Guide for Fieldworkers. 2nd ed. Lanham, MD: AltaMira, 2011.

El-Tayeb, Fatima. Undeutsch: Die Konstruktion des Anderen in der postmigrantischen Gesellschaft. Berlin: De Gruyter, 2016. https://doi.org/10.14361/9783839430743.

Erll, Astrid. "Remembering across Time, Space, and Cultures: Premediation, Remediation and the 'Indian Mutiny." In Mediation, Remediation, and the Dynamics of Cultural Memory, edited by Astrid Erll and Ann Rigney, 109-38. Berlin: De Gruyter, 2009. https://doi.org/10.1515/9783110217384.2.109.

Gilbert, Shirli. "Buried Monuments: Yiddish Songs and Holocaust Memory.” History Workshop Journal 66, no. 1 (2008): 107-28. https://doi.org/10.1093/hwj/dbn026.

Gilbert, Shirli. Music in the Holocaust: Confronting Life in the Nazi Ghettos and Camps. New York: Oxford University Press, 2005.

Ghilani, Djouaria, Olivier Luminet, Hans-Peter Erb, Christine Flassbeck, Valérie Rosoux, Ismee Tames, and Olivier Klein. "Looking Forward to the Past: An Interdisciplinary Discussion on the Use of Historical Analogies and Their Effects." Memory Studies 10, no. 3 (2017): 274-85. https://doi.org/10.1177/1750698017701609.

Güler Saied, Ayla. Rap in Deutschland: Musik als Interaktionsmedium zwischen Partykultur und urbanen Anerkennungskämpfen. Bielefeld: Transcript, 2012. https://doi.org/10.14361/transcript.9783839422519.

Güran-Aydin, Pinar, and Tia DeNora. "Remembering through Music: Turkish Diasporic Identities in Berlin.” In Routledge International Handbook of Memory Studies, edited by Anna Lisa Tota and Trever Hagen, 233-46. London: Routledge, 2016. 
Kahveci, Çağrı, and Özge Pınar Sarp. "Von Solingen zum NSU: Rassistische Gewalt im kollektiven Gedächtnis von Migrant`Innen türkischer Herkunft.” In Den NSU-Komplex analysieren, edited by Juliane Karakayali, Çagri Kahveci, Doris Liebscher and Carl Melchers, 37-56. Bielefeld: Transcript, 2017. https://doi.org/10.14361/9783839437094-004.

Kaya, Asiye. "Inclusion and Exclusion of Immigrants and the Politics of Labeling." In Migration, Memory, and Diversity: Germany from 1945 to the Present, edited by Cornelia Wilhelm, 56-85. New York: Berghahn, 2016.

Knapp, Gisela. Das Frauenorchester in Auschwitz: Musikalische Zwangsarbeit und ihre Bewältigung. Hamburg: Bockel, 1996.

Knopf, Jan, ed. Brecht Handbuch, Vol. 2: Gedichte. Stuttgart: Metzler, 2001. https://doi.org/10.1007/9783-476-05609-2.

Landsberg, Alison. Prosthetic Memory: The Transformation of American Remembrance in the Age of Mass Culture. New York: Columbia University Press, 2004.

Levi, Neil, and Michael Rothberg. "Memory Studies in a Moment of Danger: Fascism, Postfascism, and the Contemporary Political Imaginary.” Memory Studies 11, no. 3 (2018): 355-67. https://doi.org/10.1177/1750698018771868.

Microphone Mafia. Per La Vita. Al Dente Records, 2009.

Microphone Mafia. La Vita Continua. Al Dente Records, 2013.

Osses, Dietmar, and Katarzyna Nogueira. "Representations of Immigration and Emigration in Germany's Historic Museums.” In Migration, Memory, and Diversity: Germany from 1945 to the Present, edited by Cornelia Wilhelm, 155-75. New York: Berghahn, 2016. https://doi.org/10.2307/j.ctvswx6wf.11.

Oware, Matthew. I Got Something to Say: Gender, Race, and Social Consciousness in Rap Music. Cham, Switzerland: Springer, 2018. https://doi.org/10.1007/978-3-319-90454-2.

Quent, Matthias. Rassismus, Radikalisierung, Rechtsterrorismus. 2nd ed. Weinheim, Germany: Beltz, 2019.

Rajewsky, Irina. "Intermediality, Intertextuality, and Remediation: A Literary Perspective on Intermediality." Intermédialités: Histoire et théorie des arts, des lettres et des techniques 6 (2005): 43. https://doi.org/10.7202/1005505ar.

Reitsamer, Rosa. "Not Singing in Tune: The Hor 29 Novembar Choir and the Invention of a Translocal Do-It-Yourself Popular Music Heritage in Austria." Popular Music and Society 39, no. 1 (2016): 5975. https://doi.org/10.1080/03007766.2015.1061347.

Rigney, Ann. "Cultural Memory Studies: Mediation, Narrative, and the Aesthetic." In Routledge International Handbook of Memory Studies, edited by Anna Lisa Tota and Trever Hagen, 65-76. London: Routledge, 2016.

Rothberg, Michael. "Multidirectional Memory in Migratory Settings: The Case of Post-Holocaust Germany.” In Transnational Memory: Circulation, Articulation, Scales, edited by Chiara De Cesari and Ann Rigney, 123-46. Berlin: De Gruyter, 2014. https://doi.org/10.1515/9783110359107.123.

Rothberg, Michael. Multidirectional Memory: Remembering the Holocaust in the Age of Decolonization. Stanford: Stanford University Press, 2009.

Schoop, Monika E. "Standing up against Discrimination and Exclusion: An Interview with Kutlu Yurtseven.” In Made in Germany: Studies in Popular Music, edited by Oliver Seibt, Martin Ringsmut, and David-Emil Wickström, 207-15. New York: Routledge, 2020. https://doi.org/10.4324/9781351200790-26. 
Soditt, Hanna, and Fiona Schmidt. "Staatliche Kollusion im NSU-Komplex." In Den NSU-Komplex analysieren, edited by Juliane Karakayali, Çagri Kahveci, Doris Liebscher, and Carl Melchers, 191208. Bielefeld: Transcript, 2017. https://doi.org/10.14361/9783839437094-012.

Wieviorka, Annette. The Era of the Witness. Ithaca, NY Cornell University Press, 2006.

Wilhelm, Cornelia. "Introduction: Migration, Memory, and Diversity: Germany from 1945 to the Present." In Migration, Memory, and Diversity: Germany from 1945 to the Present, edited by Cornelia Wilhelm, 1-11. New York: Berghahn, 2016. https://doi.org/10.2307/j.ctvswx6wf.5.

Williams, Justin A. Rhymin' and Stealin': Musical Borrowing in Hip-Hop. Ann Arbor: University of Michigan Press, 2013. https://doi.org/10.3998/mpub.3480627.

Yurtseven, Kutlu, and Rossi Pennino. Eine ehrenwerte Familie: Die Microphone Mafia - Mehr als nur Musik. Cologne: PapyRossa, 2019. 